\title{
25. ROCK-MAGNETIC STRATIGRAPHY OF LEG 108 SITES 658, 659, 661, AND 665, EASTERN TROPICAL ATLANTIC1
}

\author{
J. Bloemendal, ${ }^{2}$ J. W. King, ${ }^{2}$ L. Tauxe ${ }^{3}$ and J.-P. Valet ${ }^{4}$
}

\begin{abstract}
The results of detailed rock-magnetic measurements of selected stratigraphic intervals at Ocean Drilling Program Leg 108 Sites $658,659,661$, and 665 are as follows:

1. At Site 658 , it is likely that the entire interval was extensively affected by reductive diagenesis, resulting in the loss of fine-grained magnetite. At Sites 659 and 665, we suspect that a similar diagenetic alteration of fine-grained magnetite occurred, but that it was confined to discrete intervals. At Site 661 , the uppermost $60-70 \mathrm{mbsf}$ of the section appears to be relatively unaffected by reductive diagenesis; however, we suspect that the low carbonate content of sediments below were affected by oxidative diagenesis/authigenesis, resulting in the production of ultrafine-grained ferrimagnetic material.
\end{abstract}

2. Preliminary spectral analyses of the uppermost 70 mbsf (i.e., unaltered) rock-magnetic record at Site 661 suggest a decrease in the frequency of magnetite grain-size fluctuations after $2.9 \mathrm{Ma}$.

\section{INTRODUCTION}

Rock-magnetic measurements provide information about magnetic mineral concentration, grain size, and mineralogy. The techniques are relatively rapid (some can be made on whole cores or " $U$ " channel samples), and they are mostly nondestructive. They are being used increasingly for highresolution correlation of Ocean Drilling Program (ODP) sediment cores (e.g., Ruddiman, Sarnthein, et al., 1988; Moore et al., 1988; Prell, Niitsuma, et al., 1989). In some cases they can provide such paleoceanographic information as the resolution of glacial-interglacial cycles and the detection of various terrigenous fluxes (e.g., Robinson, 1986; Bloemendal et al., 1988a; Doh et al., 1988; Hall et al., 1989).

Leg 108 core material afforded an opportunity to see if the strong rock-magnetic/paleoclimatic relationships detected in late Quaternary eastern tropical Atlantic sediments (Bloemendal et al., 1988a) also occurred in significantly older sediments from the same region and, if so, to use the rock-magnetic record as an aid in the reconstruction of the paleoceanographic record at these sites. In this paper, we evaluate the suitability of rock-magnetic records from four Leg 108 sites for use as paleoceanographic indicators by determining the extent to which the "primary" rock-magnetic stratigraphy (i.e., the sediment magnetic mineral content at the time of deposition) has been subjected to subsequent chemical/biochemical alteration. We also assess the paleoclimatic significance of the rock-magnetic record from one of the sites.

In this study, we concentrate our efforts on Sites 658, 659, 661 , and 665 . The sediments from Site 657 were significantly disturbed during coring, and the results of whole-core susceptibility measurements from Sites 662-664 and 666 indicated extremely low concentrations of magnetic material (Ruddiman, Sarnthein, et al., 1988).

\footnotetext{
${ }^{1}$ Ruddiman, W., Sarnthein, M., et al., 1989. Proc. ODP, Sci. Results, 108: College Station, TX (Ocean Drilling Program).

2 Graduate School of Oceanography, University of Rhode Island, Narragansett, RI 02882-1197.

${ }^{3}$ Scripps Institution of Oceanography, La Jolla, CA 92093.

4 Centre des Faibles Radioactivités, Laboratoire Mixte CNRS-CEA, Parc du CNRS, B.P. 91198 , Gif/Yvette Cedex, France.
}

\section{METHODS}

\section{Composite Sections}

Because of the unreliability of Deep Sea Drilling Project/ODP drilling depths and the frequency of stratigraphic discontinuities and sediment disturbance at core breaks (e.g., Ruddiman et al., 1986), we sampled the cores on a composite section basis. This involves taking samples from along a "pathway" that alternates between two or more paired holes so that disturbed or missing intervals are bypassed. Sample depths are recorded as depths within the composite section rather than as drilling depths (see Ruddiman, Sarnthein, et al., 1988).

For Leg 108 sites, pathways were constructed from between-hole correlations based on high-resolution (3- to $5-\mathrm{cm}$ intervals), wholecore susceptibility measurements (Bloemendal et al., 1988b). Cores recovered with the extended core barrel (XCB) were too disturbed to permit detailed between-hole correlations. Therefore, because a high degree of stratigraphic resolution was a major aim of the study, we only sampled intervals recovered with the advanced hydraulic piston corer (APC).

\section{Sampling}

Samples were obtained by pushing an oriented square-section stainless steel tube into the split core face. The resulting minicore was withdrawn and extruded into a $5-\mathrm{ml}$ plastic cube. Site 658 was sampled at $20-\mathrm{cm}$ intervals to a composite depth of $77 \mathrm{~m}$ below the seafloor (mbsf); Sites 659, 661, and 665 were sampled at $10-\mathrm{cm}$ intervals to composite depths of 93,86 , and $54 \mathrm{mbsf}$, respectively.

\section{Magnetic Measurements}

Sample processing for magnetic measurements consisted of the following steps:

1. Measurement of the natural remanent magnetization (NRM) of all specimens using a two-axis Superconducting Technology cryogenic magnetometer.

2. For Sites 661 and 665 , stepwise alternating-field (AF) demagnetization was performed on at least 10 pilot samples; no AF demagnetization was performed on the samples from Sites 658 and 659. These results were used to determine a field for subsequent blanket AF demagnetization. Possible relationships between the quality of the paleomagnetic declination and inclination records and rock-magnetic properties will be discussed in a later paper.

3. Measurement of low field $(0.1 \mathrm{mT})$ volume magnetic susceptibility $(\mathrm{K})$ at a driving field frequency of $0.47 \mathrm{kHz}$ was made with a Bartington Instruments susceptibility meter and MSIB dualfrequency sensor. All samples were measured at this frequency. The susceptibility of selected samples was measured at a frequency of 4.7 
$\mathrm{kHz}$; this is denoted as $\mathrm{K}_{\mathrm{hf}}$. The ratio of the two measurements $\left(\mathrm{K}_{\mathrm{hf}} / \mathrm{K}\right)$ was used as a measure of the frequency dependence of susceptibility. All susceptibilities were corrected for the average diamagnetic susceptibility of the plastic sample holder.

4. Demagnetization of all samples at $90 \mathrm{mT}$ to remove the NRM was followed by the acquisition of anhysteretic remanent magnetization (ARM) by subjecting samples to a gradually decreasing peak AF of $100 \mathrm{mT}$ in the presence of an $0.1 \mathrm{mT}$ direct current (DC) field. The ARM was measured using the cryogenic magnetometer. The ARMs are expressed as an anhysteretic susceptibility $\left(\mathrm{K}_{\mathrm{ARM}}\right)$, obtained by dividing by the strength of the DC field.

5. All samples were given a saturation isothermal remanent magnetization (SIRM) in a 1-T DC field, measured with DIGICO and MINISPIN fluxgate magnetometers, subjected to a reversed DC field of $0.3 \mathrm{~T}$, and then remeasured. The two measurements were used to calculate HIRM ("hard" IRM), which is defined as

$$
\left(\text { IRM }_{-0.3 \mathrm{~T}}+\mathrm{SIRM}\right) / 2,
$$

and $\mathrm{S}_{0.3 \mathrm{~T}}$, which is defined as

$$
-\mathrm{IRM}_{-0.3 \mathrm{~T}} / \mathrm{SIRM} \text {. }
$$

In the following we briefly outline the rock-magnetic significance of these parameters. The $\mathrm{K}, \mathrm{SIRM}, \mathrm{K}_{\mathrm{ARM}}$, and NRM usually reflect variations in the concentration of ferrimagnetic minerals (i.e., members of the magnetite-ulvospinel and magnetite-maghemite solid solution series, henceforth described as "magnetite"). However, K and SIRM are biased toward coarser-grained magnetite and $\mathrm{K}_{\mathrm{ARM}}$ and NRM toward finer-grained magnetite. The NRM also partly reflects the intensity of the ambient geomagnetic field at around the time of sediment deposition. The HIRM is proportional to the concentration of such high-coercivity, antiferromagnetic minerals as goethite and hematite.

For magnetic mineral assemblages dominated by magnetite, the ratio $\mathrm{K}_{\mathrm{ARM}} / \mathrm{K}$ is indicative of magnetite grain size within the magnetically stable fraction; that is, grains that span the range of stable single-domain through multidomain behavior (e.g., Hartstra, 1982a, 1982b; King et al., 1982; Ozdemir and Banerjee, 1982). The presence of hyperfine-grained magnetite (grain size less than $\sim 0.05-\mu \mathrm{m}$ diameter) can be detected by the occurrence of significant frequency dependence of susceptibility (e.g., Mullins and Tite, 1973; Bloemendal et al., 1985). The $S_{0.3}$ values reflect the ratio of goethite/hematite to magnetite, with lower values indicating an increase in this ratio.

We have found that these rapidly measured parameters are more appropriate for stratigraphic studies involving large numbers of samples than more time-consuming techniques, such as the measurement of high field magnetization and remanent magnetization hysteresis, IRM acquisition characteristics, and the variation of magnetic properties with temperature. However, our rock-magnetic inferences on the Leg 108 material will be checked by in-progress studies with these other techniques.

\section{Age Modeling}

For Sites 659,661 , and 665 , continuous age-depth relationships were obtained by fitting spline functions (De Boor, 1978) to the bioand magnetostratigraphic age datums given in Ruddiman, Sarnthein, et al. (1988). Sample ages were then obtained by interpolation of the spline function. For Site 658, an age model was obtained by correlating part of its oxygen isotope record (Sarnthein and Tiedemann, this vol.) with the SPECMAP oxygen isotope master curve (Imbrie et al., 1984). An inverse correlation method (Martinson et al., 1982) was used, implemented with the CORPAC package (D. G. Martinson, pers. comm., 1988). Thus, each oxygen isotope value was directly assigned an age. Rock-magnetic samples were then assigned an age by linear interpolation.

\section{RESULTS}

For each site, Figures 1-8 show (1) selected rock-magnetic parameters and interparametric ratios plotted vs. composite depth and (2) HIRM, K, and $\mathrm{K}_{\mathrm{ARM}}$ transformed to "accumulation rates," calculated as the product of the volume magne- tization (or susceptibility) and the sedimentation rate plotted vs. age. This should eliminate the dilution effect of variations in the accumulation rate of other sedimentary components (e.g., carbonate) on the concentration of magnetic material.

The data have been smoothed (low-pass filtered) to remove spurious high-frequency variations in calculated magnetic accumulation rates caused by short-term variations in sedimentation rate that cannot be resolved by our age models. Selected interparametric ratios are included for comparison. These plots also enable long-term trends in the rock-magnetic stratigraphy to be seen more clearly.

\section{Site 658}

Site 658 is located in $2263 \mathrm{~m}$ water depth on the continental slope $160 \mathrm{~km}$ west of Cap Blanc, beneath a permanent upwelling cell generated by the northern trades. The lithology of the sampled interval is nannofossil ooze, with carbonate content ranging from $30 \%$ to $70 \%$; the sedimentation rate averages $147 \mathrm{~m} / \mathrm{m} . y$. (Ruddiman, Sarnthein, et al., 1988). Each of the parameters reflecting variations in the concentration of magnetic material (HIRM, $\mathrm{K}, \mathrm{K}_{\mathrm{ARM}}$, and NRM) shows a significant peak in the top $\sim 1$ mbsf (Holocene) of the section (Fig. 1). For K, SIRM, and $\mathrm{K}_{\mathrm{ARM}}$, this is the largest peak in the section. Also, HIRM shows two large peaks (and $\mathrm{S}_{0.3 \mathrm{~T}}$ shows two pronounced minima) in the interval around 8-2 mbsf, which corresponds to oxygen isotope stage 2 (Sarnthein and Thiede, this vol.). Below this depth, most of the rockmagnetic parameters appear to vary in a cyclic manner with depth.

To test whether these variations were related to glacialinterglacial cycling, the rock-magnetic data were converted to a time series, linearly interpolated to $2-\mathrm{k}$.y. intervals, and cross-correlated with the SPECMAP oxygen isotope master curve (Imbrie et al., 1984), which is proportional to global ice volume (Fig. 2). None of the parameters were strongly correlated with the SPECMAP record. The $\mathrm{K}_{\mathrm{ARM}}$ and SIRM had the highest cross-correlation coefficients $(R=0.5$, with no significant lag), with higher values corresponding to periods of higher global ice volume. The accumulation rate plots show that the accumulation rate of magnetic material at this site was significantly lower than at the three other sites (see below).

\section{Site 659}

Site 659 is located in $3070 \mathrm{~m}$ water depth on the top of the Cape Verde Rise and lies beneath the Saharan Air Layer, a wind system responsible for the large-scale transport of eolian dust over the eastern tropical Atlantic (Sarnthein et al., 1982). The interval used for rock-magnetic measurements consists of interbedded nannofossil ooze and foraminifer-nannofossil ooze, with minor amounts of silt and clay. Carbonate content ranges from about $40 \%$ to $90 \%$, and the sedimentation rate averages $30 \mathrm{~m} / \mathrm{m} . y$. (Ruddiman, Sarnthein, et al., 1988).

The off-scale peaks in the magnetic concentration parameters (best seen in the $\mathrm{K}$ record) probably correspond to volcanic ash layers with high concentrations of ferrimagnetic minerals; most of them occur in the upper 30 mbsf. Ignoring these off-scale peaks, the magnetic concentration parameters show roughly cyclic variations with depth. The number of cycles per meter ranges from about 1 to 3 . Given the average sedimentation rate over this interval, this places them within the Milankovitch periodicity band (104-105 yr) (Berger et al., 1984).

Above about $15 \mathrm{mbsf}$, the amplitude of the fluctuations in $\mathrm{K}_{\mathrm{ARM}} / \mathrm{K}$ (indicative of variations in magnetic grain size) tends to decrease (Fig. 3). There are several intervals in which very low values of $\mathrm{K}_{\mathrm{ARM}} / \mathrm{K}$ (and $\mathrm{K}_{\mathrm{ARM}}$ ) extend over several meters (e.g., around $17-14 \mathrm{mbsf}$ ). The intervals from 65 to $52 \mathrm{mbsf}$ and from 
ROCK-MAGNETIC STRATIGRAPHY OF SITES 658, 659, 661, AND 665

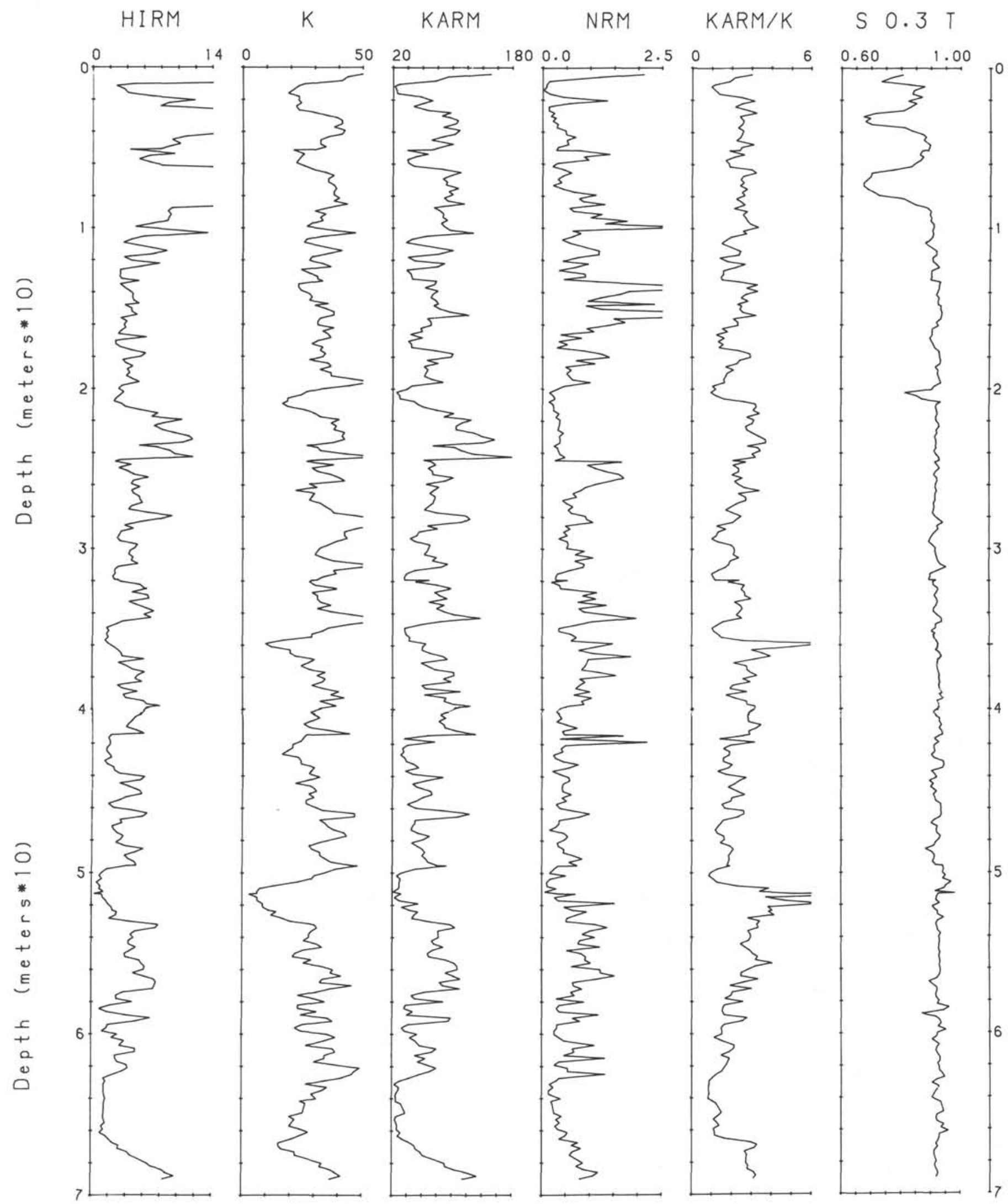

Figure 1. Rock-magnetic stratigraphy of Site 658 . Units: $\mathrm{K} ; \mathrm{K}_{\mathrm{ARM}} \times 10^{-9} \mathrm{SI}$ units; HIRM $\times 10^{-6} \mathrm{~A} / \mathrm{m}$. 
98 to 73 mbsf also tend to have low overall values for these ratios. These intervals also have significantly reduced $\mathrm{S}_{0.3 \mathrm{~T}}$ values (increased goethite/hematite:magnetite ratio). In Figure 4 the intervals of low $\mathrm{K}_{\mathrm{ARM}} / \mathrm{K}$ are marked with vertical bars. The "magnetic accumulation rate" plots show a trend of increasing values after about $2.5 \mathrm{~m}$.y. ago; this is more pronounced in the case of HIRM than for the other parameters.

\section{Site 661}

Site 661 is located in $4013 \mathrm{~m}$ water depth on the eastern slope of the Kane Gap, a major deep-water passage northeast of the Sierra Leone Rise. Detailed whole-core susceptibility correlations are possible over the lower Pleistocene through lower Pliocene intervals between this site and Site 660 , located about $40 \mathrm{mi}$ northeast (Ruddiman, Sarnthein, et al., 1988).

The interval used for rock-magnetic measurements spans lithologic Unit I (interbedded nannofossil ooze and muddy nannofossil ooze) and the uppermost part of lithologic Unit II (interbedded silty clay and nannofossil ooze). Carbonate content averages around $50 \%-60 \%$ in the upper 60 mbsf and then decreases to near zero (Ruddiman, Sarnthein, et al., 1988). As at Site 659, the rock-magnetic parameters show a pattern of high-frequency variation (around 1-3 cycles per meter) (Fig. 5).

Above 50 mbsf, all of the magnetic concentration parameters decrease significantly, paralleling an increase in carbonate content that reflects the relative position of the site above the carbonate-compensation depth (CCD) at this time. This trend also coincides with a significant decrease in the frequency dependence of susceptibility (increased $\mathrm{K}_{\mathrm{hf}} / \mathrm{K}$ ratio), decreased $\mathrm{K}_{\mathrm{ARM}} / \mathrm{K}$, and decreased $\mathrm{S}_{0.3 \mathrm{~T}}$ values. Figure 6 shows these long-term trends more clearly.

In the magnetic accumulation rate plots, HIRM is the only parameter that increases more or less continuously after about 2.2 m.y. ago (cf. Site 659). These plots also show that the strong relative decrease in $\mathrm{K}, \mathrm{NRM}$, and especially $\mathrm{K}_{\mathrm{ARM}}$ after about $4 \mathrm{Ma}$ is amplified on an accumulation rate basis. The smoothed $\mathrm{K}_{\mathrm{ARM}} / \mathrm{K}$ record shows a trend of continuously decreasing values (coarsening of the magnetite grain-size distribution) throughout the section.

\section{Site 665}

Site 665 is located in $4746 \mathrm{~m}$ of water on the southeastern margin of the Sierra Leone Rise. The interval used for rock-magnetic measurements consists of interbedded nannofossil and foraminifer-nannofossil oozes. Carbonate content ranges from $30 \%$ to $80 \%$ (Ruddiman, Sarnthein, et al., 1988). Three main points can be made:

1. The rock-magnetic parameters show similar high-frequency fluctuations to those seen at the other sites.

2. Above about 35 mbsf, HIRM, $\mathrm{K}_{\mathrm{ARM}}, \mathrm{NRM}$, and $\mathrm{K}_{\mathrm{ARM}} / \mathrm{K}$ increase significantly from near base-line values; $\mathrm{S}_{0.3 \mathrm{~T}}$ increases somewhat over the same interval (Fig. 7). These data suggest an increase in the concentration of magnetic material, a fining of the magnetite grain-size distribution, and a decrease in the ratio of goethite/hematite to magnetite.

3. Above $35 \mathrm{mbsf}$, there are intervals with similar magnetic properties to those below 35 mbsf (i.e., low $\mathrm{K}, \mathrm{K}_{\text {ARM }}$, HIRM, $\mathrm{K}_{\mathrm{ARM}} / \mathrm{K}$, and decreased $\mathrm{S}_{0.3 \mathrm{~T}}$ ). The most pronounced occurs at 11-9 mbsf. Others occur at about $31,22,18,14,7$, and 4 mbsf.

Figure 8 shows that the strong increase in magnetic mineral concentration above $35 \mathrm{mbsf}$ (around $1.5 \mathrm{Ma}$ ) is also evident on an accumulation rate basis and therefore is not caused by changes in the accumulation rate of other sedimentary com- ponents. Figure 8 also shows that there is an overall trend of decreasing $\mathrm{K}_{\mathrm{ARM}} / \mathrm{K}$ (coarsening of the magnetite grain-size distribution) after about 1.5 Ma.

\section{Between-Site Comparison of Magnetite Concentration and Grain Size}

Figure 9 shows plots of $\mathrm{K}_{\mathrm{ARM}}$ vs. $\mathrm{K}$ for (1) combined data from Sites 658 (with fitted regression line) and 661, (2) 659, and (3) 665 . For Sites 658 and 665 , all of the data are plotted; for Sites 659 and 661 , very strongly magnetic samples (from the volcanic ash layers at Site 659 and the low carbonate content interval at the base of the measured interval at Site 661) are excluded. Increasing magnetite concentration is shown by increasing distance of points from the origin and decreasing magnetite grain size by increasing gradient of the line joining each point to the origin.

Given various assumptions (King et al., 1982), these plots can be used to estimate absolute magnetite concentration and grain size. These assumptions cannot be made for the Leg 108 sediments; however, the plots can still be used to illustrate relative differences in magnetite concentration and grain size between the sites. The following points can be made:

1. At Site 658 , the magnetite concentration is lower (points close to the origin), the magnetite grain size significantly coarser (shallow gradient of the regression line), and the grain-size range relatively narrow (low scatter around the regression line) in comparison with the other sites.

2. Sites 659 and 665 have a similar range of magnetite concentration and grain size. Each also has a distinct subgroup of points with low $\mathrm{K}_{\mathrm{ARM}}, \mathrm{K}$, and $\mathrm{K}_{\mathrm{ARM}} / \mathrm{K}$ values that resemble the distribution for Site 658 .

3. The samples from Site 661 have higher magnetite concentrations and finer magnetite grain sizes in comparison with the other sites, and there is no distinct subgroup of samples resembling the distribution for Site 658 .

\section{DISCUSSION AND FURTHER ANALYSIS OF THE ROCK-MAGNETIC RECORD FOR SITE 661}

\section{Postdepositional Alteration of Magnetic Minerals}

The use of Leg 108 rock-magnetic data as a paleoceanographic indicator requires the recognition of possible postdepositional alteration of the primary rock-magnetic stratigraphy. We suggest that such alterations have been extensive at the sites investigated.

Diagenesis of magnetite to nonmagnetic forms in suboxic/ anoxic hemipelagic marine sediments is well documented (e.g., Karlin and Levi, 1983; Van Vreumingen, 1984; Canfield and Berner, 1987). Fine-grained magnetite appears to be more susceptible to dissolution than coarser-grained magnetite because of its relatively large surface-area-to-volume ratio. At Site 658 , upwelling generated high organic productivity in the water column, resulting in high sedimentary organic carbon contents and strongly reducing conditions (Ruddiman, Sarnthein, et al., 1988).

Because of this, and in view of the inferred absence of fine-grained magnetite at this site, it seems likely that the sediments have undergone a significant diagenetic loss of magnetite. This is further supported by the fact that calculated magnetic accumulation rates at this site are about one order of magnitude lower than at the other sites. Site 658 would be expected to have received an abundant supply of fluvialderived and wind-transported magnetic minerals. Therefore, we conclude that the use of its rock-magnetic stratigraphy to infer variations in terrigenous fluxes is probably unwarranted.

This alteration of the primary stratigraphy may be the reason for the weak correlations between the rock-magnetic 


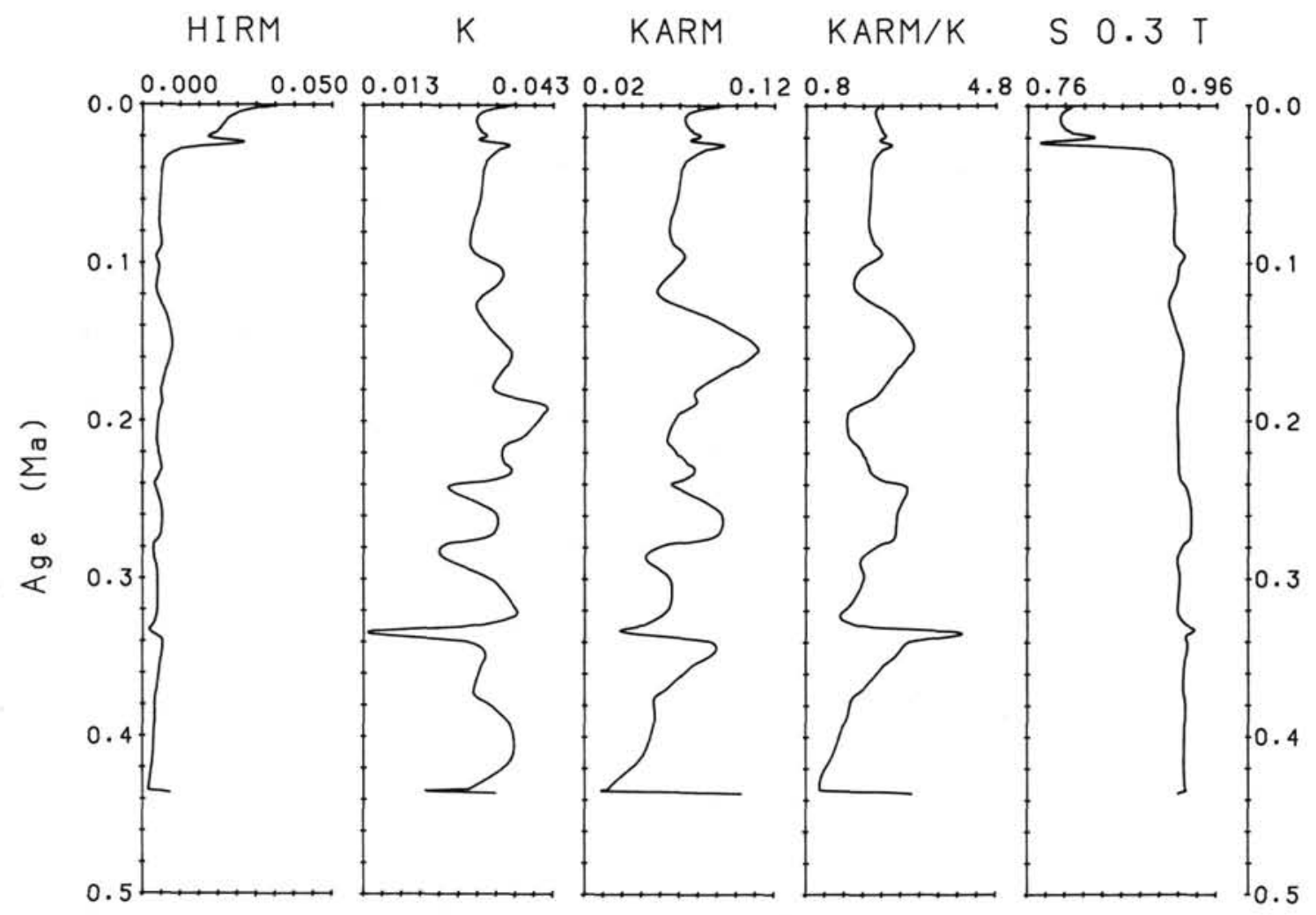

Figure 2. Magnetic accumulation rates for Site 658 . Units: $\mathrm{K} ; \mathrm{K}_{\mathrm{ARM}} \times 10^{-6} \mathrm{~m} / \mathrm{Ma} ; \mathrm{HIRM} \times 10^{-3} \mathrm{~A} / \mathrm{m} . \mathrm{y}$.

parameters and the SPECMAP oxygen isotopic master curve. It is interesting that despite this inferred loss of fine-grained magnetite, the site still has a high-quality geomagnetic polarity record (Tauxe et al., this vol.).

The records from Sites 659 and 665 contain intervals in which $\mathrm{K}$, NRM, HIRM, and $\mathrm{K}_{\mathrm{ARM}}$ drop to near base-line values, the reduction always being greatest in the case of $\mathrm{K}_{\mathrm{ARM}}$. Two observations may be significant:

1. Some of these intervals are of significantly longer duration than a typical oxygen isotopic "event" and, therefore, are unlikely to be related to climatically controlled variations in terrigenous flux.

2. The $\mathrm{K}_{\mathrm{ARM}} / \mathrm{K}$ ratios of these intervals are similar to those of Site 658 sediments, which we are confident have undergone significant diagenetic loss of magnetite. From this we can conclude that they represent periods when the sedimentary environment was inimical to the preservation of magnetic minerals, especially fine-grained magnetite. This could be the result of increased organic matter flux to the sediments (increased productivity) or the increased preservation of organic matter in the sediments.

Each of these could lead to the increased use of iron oxides (including magnetic forms) in suboxic organic matter diagenesis (Froelich et al., 1979). Some of these intervals at the two sites appear to be approximately synchronous (e.g., the interval from 0.5 to $0.4 \mathrm{Ma}$ ). At Site 665 , low $\mathrm{K}_{\mathrm{ARM}} / \mathrm{K}$ ratios occur at the base of the sampled interval (below about 35 mbsf, which corresponds from at least 2.5 to about $1.5 \mathrm{Ma}$ ). This time interval also coincides with generally low $\mathrm{K}_{\mathrm{ARM}} / \mathrm{K}$ ratios at Site 659. This suggests the persistence of oceanographic/ sedimentary conditions inhibiting the preservation of finegrained magnetite for at least $1 \mathrm{~m} . \mathrm{y}$. However, without additional geochemical data, we cannot at present exclude the possibility that the intervals of low $\mathrm{K}_{\mathrm{ARM}} / \mathrm{K}$ ratios reflect a reduction in the flux of fine-grained magnetite to the sediments rather than a preservational artifact.

At Site 661 there are no extended intervals of low $\mathrm{K}_{\mathrm{ARM}} / \mathrm{K}$ (such as those occurring at the other sites), which we suggest indicates that reduction diagenesis of magnetite has been insignificant. Instead, prior to about $4 \mathrm{Ma}$, there is a major increase in $\mathrm{K}_{\mathrm{ARM}} / \mathrm{K}$ as well as strong increases in magnetic concentration parameters and magnetic accumulation rates, shown especially by $\mathrm{K}_{\mathrm{ARM}}$, and increased frequency dependence of susceptibility. In the case of the sediments from this interval, we noted a strong viscous decay of the NRM after the samples were inserted inside the magnetically shielded measurement region of the cryogenic magnetometer. These data suggest the presence of ultrafinegrained ferrimagnetic material, some of it below the stable single-domain size limit.

It is interesting that the maximum observed $\mathrm{K}_{\mathrm{ARM}} / \mathrm{K}$ values $(>200)$ significantly exceed the values characteristic of ultrafine-grained magnetite (e.g., King et al., 1982; Hartstra, $1982 \mathrm{a}, 1982 \mathrm{~b})$. The lithology of this interval is silty clay, deposited slowly, presumably under oxidizing conditions. Several studies of Pacific "red clays" have revealed similar magnetic properties, which have been attributed either (1) to low-temperature oxidation of magnetite (Kent and Lowrie, 1974) or (2) to authigenesis of magnetic ferromanganese phases (Henshaw and Merrill, 1980). Our data shed no further light on this problem; however, they suggest that the rockmagnetic data from this site for the interval prior to $4 \mathrm{Ma}$ cannot be used to infer variations in terrigenous flux.

From the above, we conclude that of the four sites studied, the interval from 0 to $4 \mathrm{Ma}$ at Site 661 is the least affected by postdepositional alteration of "primary" magnetic minerals or by the authigenesis of new magnetic phases. This interval contains the following salient features: (1) more or less con- 


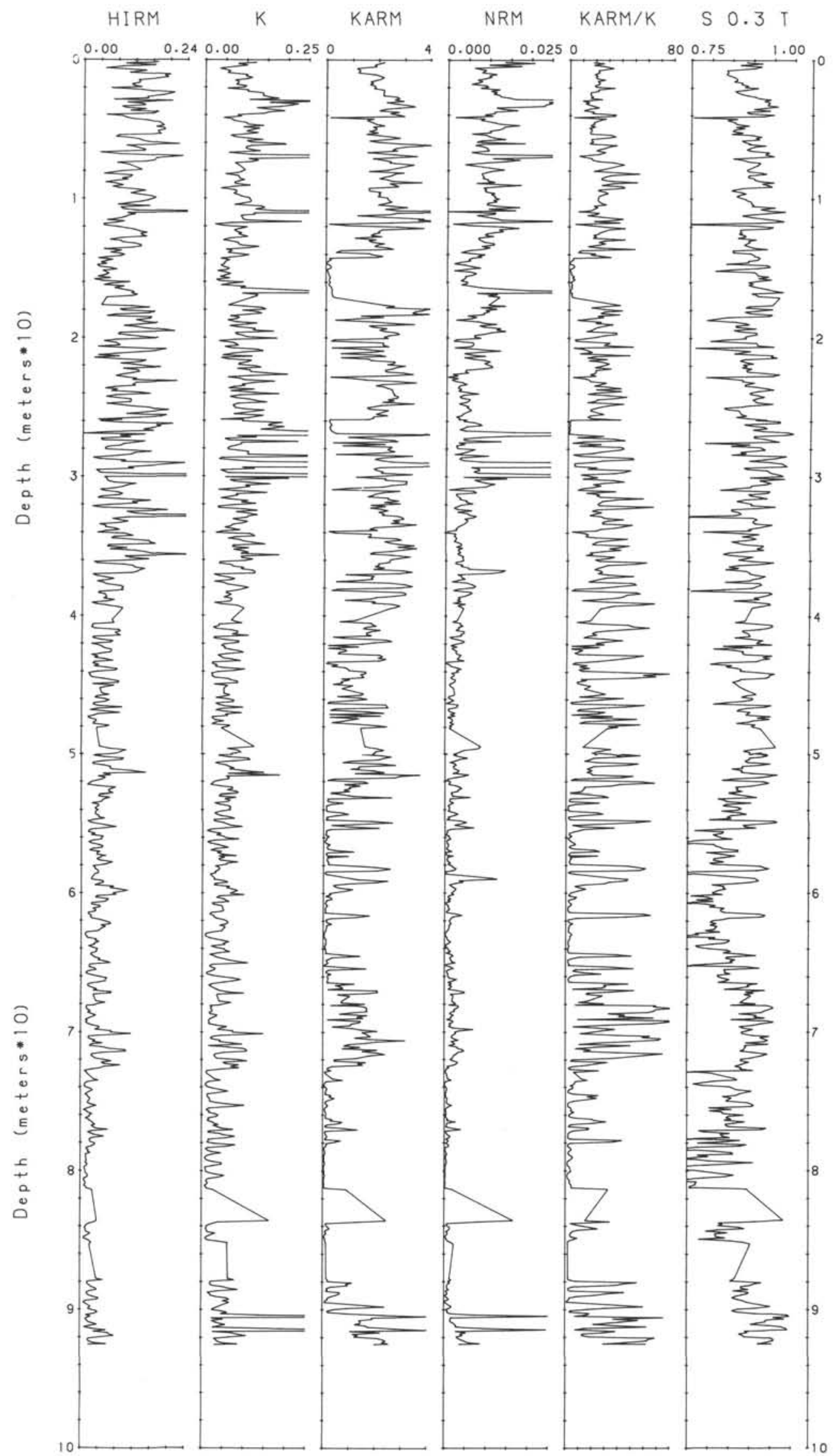

Figure 3. Rock-magnetic stratigraphy of Site 659. Units: $\mathrm{K} ; \mathrm{K}_{\mathrm{ARM}} \times 10^{-6} \mathrm{SI}$ units; HIRM $\times 10^{-3} \mathrm{~A} / \mathrm{m}$. 
tinuously increasing HIRM and $\mathrm{K}$ accumulation rates after about $2.8 \mathrm{Ma}$; (2) decreasing $\mathrm{K}_{\mathrm{ARM}}$ accumulation rates, $\mathrm{K}_{\mathrm{ARM}}$ ratios, and $\mathrm{S}$ values after about $2.8 \mathrm{Ma}$; and (3) more tentatively, a decrease in the frequency of the "Milankovitch band" rock-magnetic fluctuations evident in the unsmoothed data at about 2.8 Ma. Features 1-3 are also evident in the records from Sites 659 and 665 .

The long-term trends in the records suggest that over this time interval there was an increasing flux of both goethite/hematite and magnetite to the site (almost certainly of terrigenous origin), an increase in the goethite/hematite:magnetite ratio, and an increase in the average magnetite grain size. These general trends are consistent with the increasing aridification of northwest Africa over the last $3 \mathrm{Ma}$ and consequently increased fluxes of terrigenous matter and increased paleo-wind speeds evident in the marine record (e.g., Stein, 1985). The relationship between these rock-magnetic properties and northwest African climate in Quaternary cores from the eastern tropical Atlantic is discussed in Bloemendal et al. (1988a).

\section{Spectral Analysis of the Rock-Magnetic Record from Site 661}

If we are correct in assuming that the Site 661 interval from approximately 0 to $4 \mathrm{Ma}$ is unaffected by diagenetic/ authigenetic transformations of magnetic material, then it is likely that the rock-magnetic stratigraphy primarily reflects variations in climatically modulated fluxes of terrigenousand perhaps biogenic (e.g., Kirschvink and Chang, 1984)magnetic minerals to the sediment. Because of the apparently cyclic nature of the records, we used spectral analysis to try to detect the well-documented "Milankovitch" earth orbital periodicities (Berger et al., 1984). Confirmation of the presence of such periodicities could be significant for (1) studies of northwest African climatic development and (2) age-model refinement by "tuning" the rock-magnetic data (e.g., Martinson et al., 1987).

Because of the effect of external factors, such as carbonate dilution on magnetic mineral concentration, an interparametric ratio $\left(\mathrm{K}_{\mathrm{ARM}} / \mathrm{K}\right)$ was used for spectral analysis. Figure 10 shows the age model used, and Figure 11 shows the $\mathrm{K}_{\mathrm{ARM}} / \mathrm{K}$ time series. Figure 12 shows the results of an evolutive spectral analysis (using the Sande-Tukey radix-2 Fast Fourier Transform) for the interval from 0 to $4 \mathrm{Ma}$. Prior to the analysis the data were linearly interpolated to 6-k.y. intervals, split into $0.5-\mathrm{m} . \mathrm{y}$. intervals, and cosine tapered and zero padded to the next integer power of two points. Modified Daniell smoothing was used to obtain more reliable spectral estimates (see Bloomfield, 1976). We analyzed the same time series using the maximum entropy method (Burg, 1967); this gave very similar results.

The periodograms do not consistently show concentrations of variance at periods corresponding closely to those of the three main earth orbital parameters: eccentricity $(\sim 100$ k.y.), obliquity (41 k.y.), and precession (23-19 k.y.). This may be the result of an inaccurate age model, the presence of orbital periodicities as difference or combination tones (e.g., Pisias and Rea, 1988), or the fact that they simply are not present in the rock-magnetic record. However, the periodograms do show significant time differences in variance distribution with frequency. For example, the interval from 1.5 to $1.0 \mathrm{Ma}$ shows a dominant 45 - to $38-\mathrm{k}$.y. period (obliquity?); and the interval from 3.5 to $3.0 \mathrm{Ma}$ shows a pronounced increase in a relatively short-period component (19-17 k.y.) (precession?) in comparison with the interval from 3.0 to $2.5 \mathrm{Ma}$. This shift can be seen in Figure 11 and occurs at about $2.9 \mathrm{Ma}$.

\section{CONCLUSIONS}

From our preliminary rock-magnetic analyses of the four sites, we conclude that:

1. the sediments from the entire interval sampled at Site 658 have undergone extensive loss of fine-grained magnetite by reductive diagenesis.

2. discrete intervals at Sites 659 and 665 have been affected by the same process.

3 . the sediments of silty clay lithology at Site 661 have undergone oxidative diagenetic/authigenetic production of ultrafine-grained ferrimagnetic material.

4. there is evidence for a decrease in the frequency of fluctuations in magnetite grain size at Site 661 at about $2.8 \mathrm{Ma}$.

\section{ACKNOWLEDGMENTS}

We thank P. Gangemi, A. Helmstetter, and A. Reifsnyder for technical help; M. Sarnthein for unpublished data; P. de Menocal for valuable discussions; and the Joint Oceanographic Institutions, Inc., for financial support.

\section{REFERENCES}

Berger, A. L., Imbrie, J., Hays, J., Kukla, G., and Saltzman, B. (Eds.), 1984. Milankovitch and Climate: Hingham, MA (D. Reidel).

Bloemendal, J., Barton, C. E., and Radhakrishnamurthy, C. R., 1985. Correlation between Rayleigh loops and frequency-dependent and quadrature susceptibility: application to magnetic granulometry of rocks. J. Geophys. Res., 90:8789-8792.

Bloemendal, J., Lamb, B., and King, J. W., 1988a. Paleoenvironmental implications of rock-magnetic properties of late Quaternary sediments from the eastern equatorial Atlantic. Paleoceanography, 3:61-87.

Bloemendal, J., Tauxe, L., Valet, J.-P., and Shipboard Scientific Party, 1988b. High resolution, whole-core magnetic susceptibility logs from Leg 108. In Ruddiman, W., Sarnthein, M., et al., Proc. ODP, Init. Repts., 108: College Station, TX (Ocean Drilling Program), 1005-1013.

Bloomfield, P., 1976. Fourier Analysis of Time Series: An Introduction: New York (Wiley).

Burg, J. P., 1967. Maximum entropy spectral analysis [paper presented at SEG meeting, Oklahoma City].

Canfield, D. E., and Berner, R. A., 1987. Dissolution and pyritization of magnetite in anoxic marine sediments. Geochem. Cosmochim. Acta, 51:645-659.

De Boor, C., 1978. A Practical Guide to Splines: Berlin-HeidelbergNew York (Springer-Verlag).

Doh, S.-J., King, J. W., and Leinen, M., 1988. A rock-magnetic study of giant piston core LL44-GPC4 from the central North Pacific. Paleoceanography, 3:89-112.

Froelich, P. N., Klinkhammer, G. P., Bender, M., Luedtke, N. A., Heath, G. R., Cullen, D., and Dauphin, P., 1979. Early oxidation of organic matter in pelagic sediments of the eastern equatorial Atlantic: suboxic diagenesis. Geochim. Cosmochim. Acta, 43:1075-1090.

Hall, F. R., Bloemendal, J., King, J. W., Arthur, M. A., and Aksu, A. E., 1989. Middle to late Quaternary sediment fluxes in the Labrador Sea, ODP Leg 105, Site 647: a synthesis of rock-magnetic, oxygenisotopic, carbonate, and planktonic foraminiferal data. In Srivastava, S., Arthur, M. A., et al., Proc. ODP, Sci. Results, 105: College Station, TX (Ocean Drilling Program), 653-688.

Hartstra, R. L., 1982a. A comparative study of the ARM and Isr of some natural magnetites of MD and PSD grain size. Geophys. J. R. Astron. Soc., 71:497-518.

1982b. Grain-size dependence of initial susceptibility and saturation magnetization-related parameters of four natural magnetites in the PSD-MD range. Geophys. J.R. Astron. Soc., $71: 477-495$.

Henshaw, P. C., and Merrill, R. T., 1980. Magnetic and chemical changes in marine sediments. Rev. Geophys., 18:483-504.

Imbrie, J., Hays, J. D., Martinson, D. G., McIntyre, A., Mix, A. C., Morley, J. J., Pisias, N. G., Prell, W. L., and Shackleton, N. J., 1984. The orbital theory of Pleistocene climate: support from a revised chronology of the marine $\delta^{18} \mathrm{O}$ record. In Berger, A. L., 


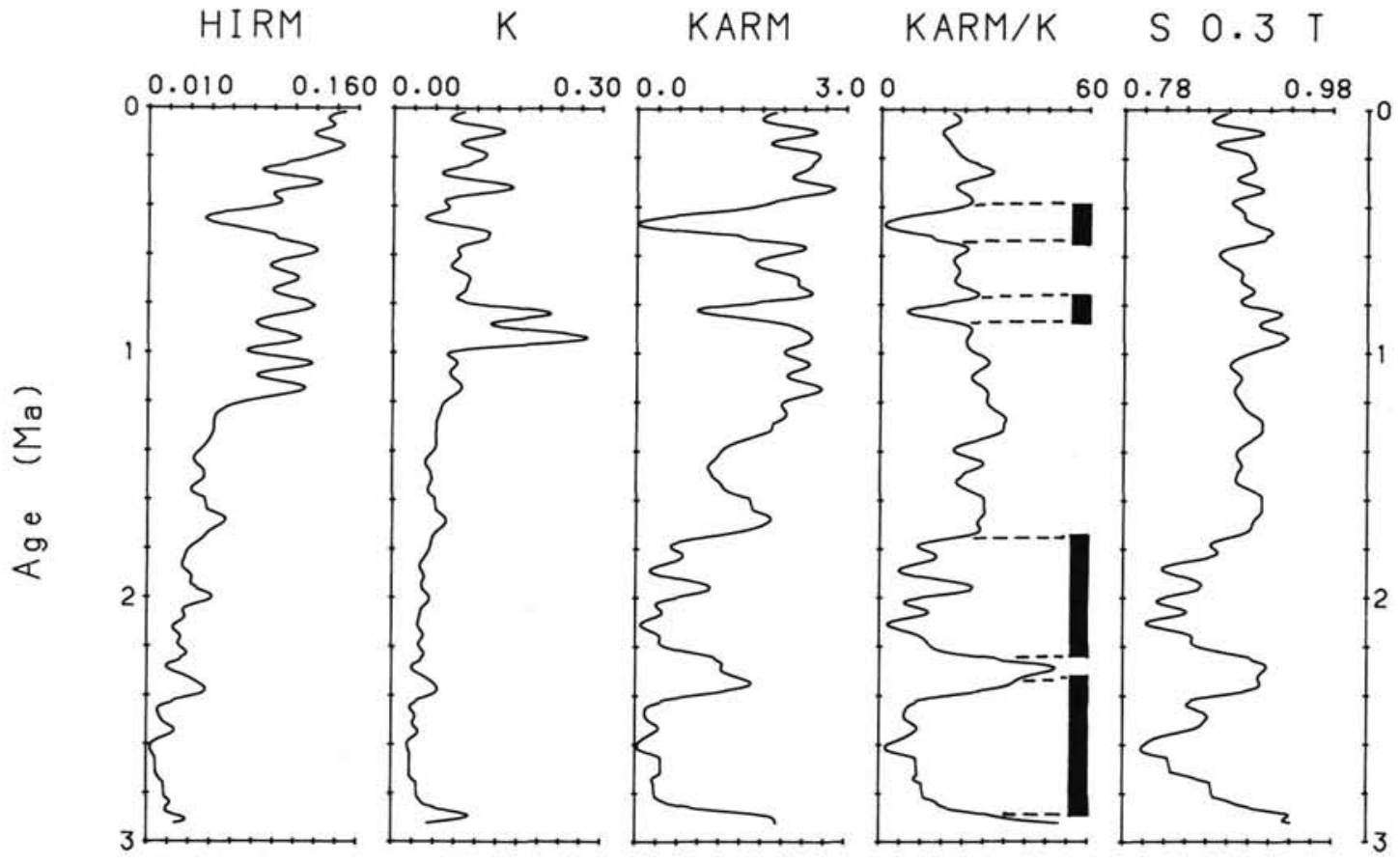

Figure 4. Magnetic accumulation rates for Site 659 . Units: $\mathrm{K} ; \mathrm{K}_{\mathrm{ARM}} \times 10^{-6} \mathrm{~m} / \mathrm{Ma} ; \mathrm{HIRM} \times 10^{-3} \mathrm{~A} / \mathrm{m} . \mathrm{y}$.

Imbrie, J., Hays, J., Kukla, G., and Saltzman, B. (Eds.), Milankovitch and Climate (Pt. 2): Hingham, MA (D. Reidel), 269-306.

Karlin, R., and Levi, S., 1983. Diagenesis of magnetic minerals in Recent hemipelagic sediments. Nature, 303:327-330.

Kent, D. V., and Lowrie, W., 1974. Origin of magnetic instability in sediment cores from the central North Pacific. J. Geophys. Res., 49:2987-3000.

King, J. W., Banerjee, S. K., Marvin, J., and Ozdemir, O., 1982. A comparison of different magnetic methods for determining the relative grain size of magnetite in natural materials: some results from lake sediments. Earth Planet. Sci. Lett., 59:404-419.

Kirschvink, J. L., and Chang, S.-B. R., 1984. Ultrafine-grained magnetite in deep-sea sediments: possible bacterial magnetofossils. Geology, 12:559-562.

Martinson, D. G., 1982. An inverse approach to signal correlation. $J$. Geophys. Res., 87:4807-4818.

Martinson, D. G., Pisias, N. G., Hays, J. D., Imbrie, J., Moore, T. C., and Shackleton, N. J., 1987. Age dating and the orbital theory of the ice ages: development of a high-resolution 0 to 300,000 year chronostratigraphy. Quat. Res., 27:1-29.

Moore, T. C., Mascle, A., et al., 1988. Proc. ODP, Init. Repts., 112: College Station, TX (Ocean Drilling Program).

Mullins, C. E., and Tite, M. S., 1973. Magnetic viscosity, quadrature susceptibility, and frequency dependence of susceptibility in single-domain assemblies of magnetite and maghemite. J. Geophys. Res., 78:804-809.

Ozdemir, O., and Banerjee, S. K., 1982. A preliminary magnetic study of soil samples from west central Minnesota. Earth Planet. Sci. Lett., 59:393-403.

Pisias, N. G., and Rea, D. K., 1988. Late Pleistocene paleoclimatology of the central equatorial Pacific: sea surface response to the southeast trade winds. Paleoceanography, 3:21-38.
Prell, W. P., Niitsuma, N., et al., 1989. Proc. ODP, Init. Repts., 117: College Station, TX (Ocean Drilling Program).

Robinson, S. G., 1986. The late Pleistocene palaeoclimatic record of North Atlantic deep-sea sediments revealed by mineral-magnetic measurements. Phys. Earth Planet. Inter., 42:22-47.

Ruddiman, W. F., Cameron, D., and Clement, B. M., 1986. Sediment disturbance and correlation of offset holes drilled with the hydraulic piston corer: Leg 94. In Ruddiman, W. F., Kidd, R. B., Thomas, E., et al., Init. Repts. DSDP, 94, Pt. 2: Washington (U.S. Govt. Printing Office), 615-634.

Ruddiman, W., Sarnthein, M., et al., 1988. Proc. ODP, Init. Repts., 108: College Station, TX (Ocean Drilling Program).

Sarnthein, M., Thiede, J., Pflaumann, U., Erlenkeuser, H., Fütterer, D., Koopmann, B., Lange, H., and Seibold, E., 1982. Atmospheric and oceanic circulation patterns off northwest Africa during the past 25 million years. In von Rad, U., Hinz, K., Sarnthein, M., and Seibold, E. (Eds.), Geology of the Northwest African Continental Margin: Berlin-Heidelberg-New York (Springer-Verlag), 545-603.

Stein, R., 1985. Late Neogene changes of paleoclimate and paleoproductivity off northwest Africa (DSDP Site 397). Palaeogeogr., Paleoclimatol., Palaeoecol., 49:47-59.

Van Vreumingen, M. J., 1984. A paleomagnetic and rock-magnetic study of sediment cores from the Zaire submarine fan. Neth. J. Sea Res., 17:342-363.

Date of initial receipt: 1 July 1988

Date of acceptance: 1 February 1989

Ms 108B-145 


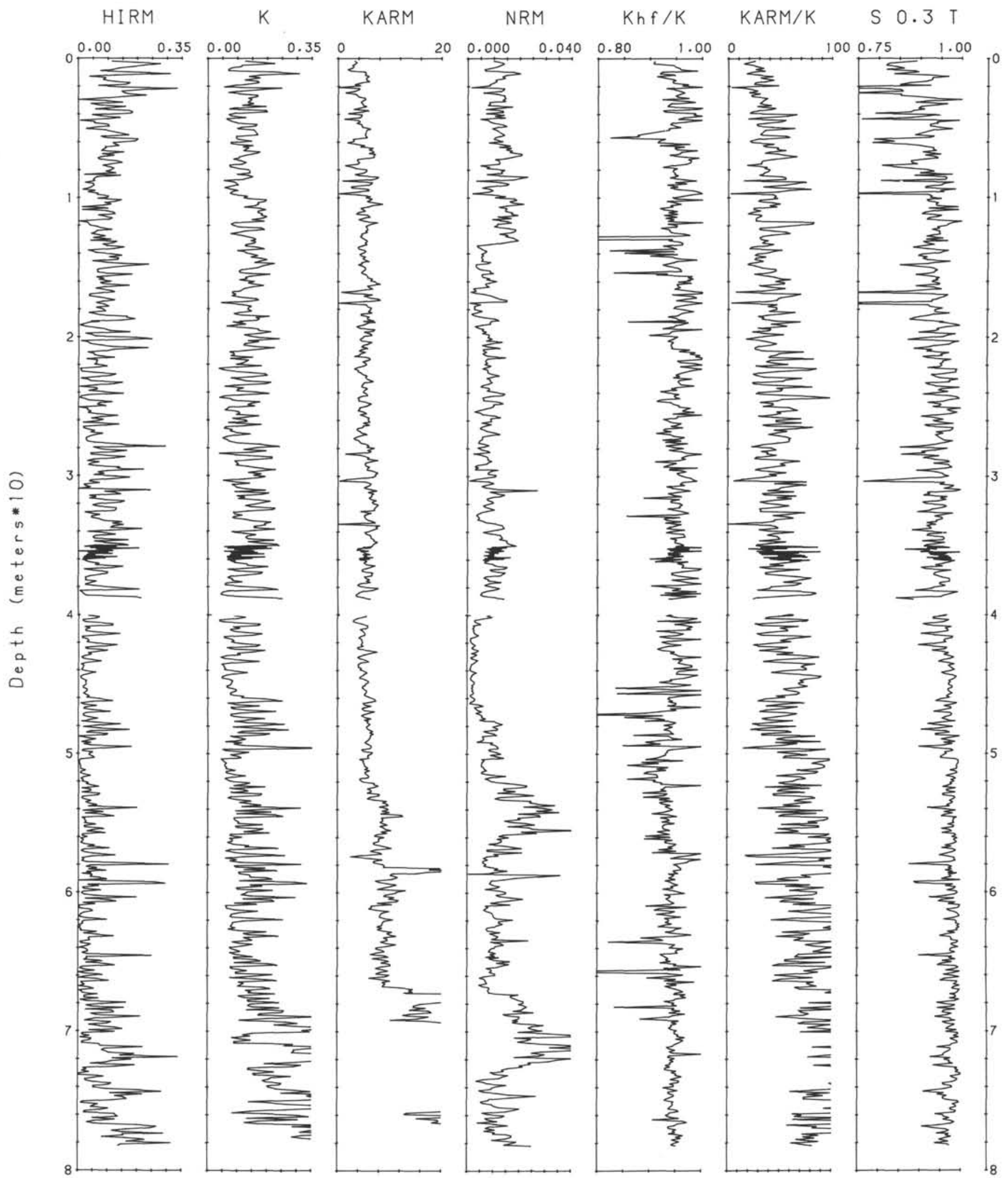

Figure 5. Rock-magnetic stratigraphy of Site 661 . Units: K; $\mathrm{K}_{\mathrm{ARM}} \times 10^{-6} \mathrm{SI}$ units; HIRM $\times 10^{-3} \mathrm{~A} / \mathrm{m}$. 


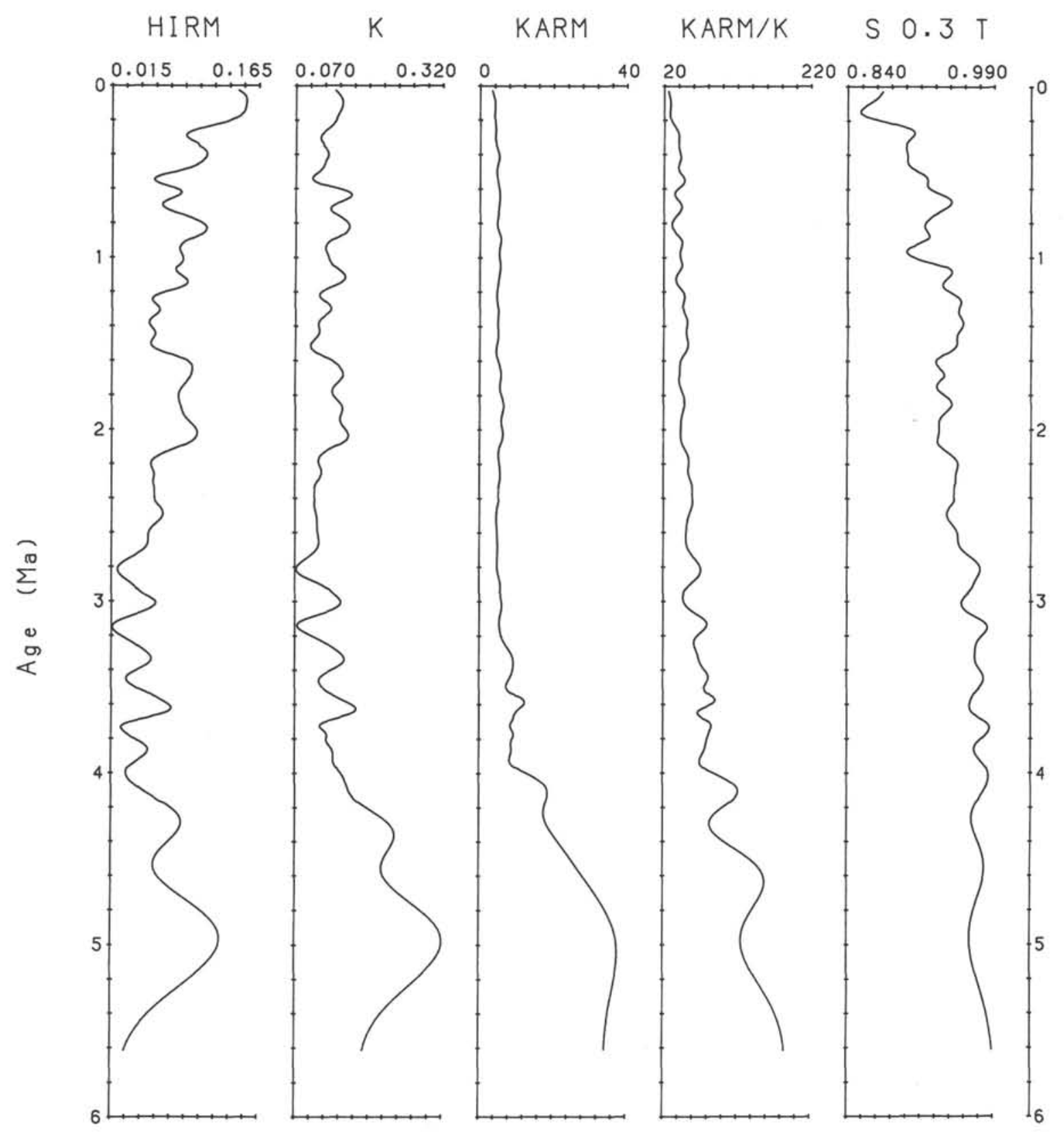

Figure 6. Magnetic accumulation rates for Site 661. Units: $\mathrm{K} ; \mathrm{K}_{\mathrm{ARM}} \times 10^{-6} \mathrm{~m} / \mathrm{Ma} ; \mathrm{HIRM} \times 10^{-3} \mathrm{~A} / \mathrm{m} . \mathrm{y}$. 


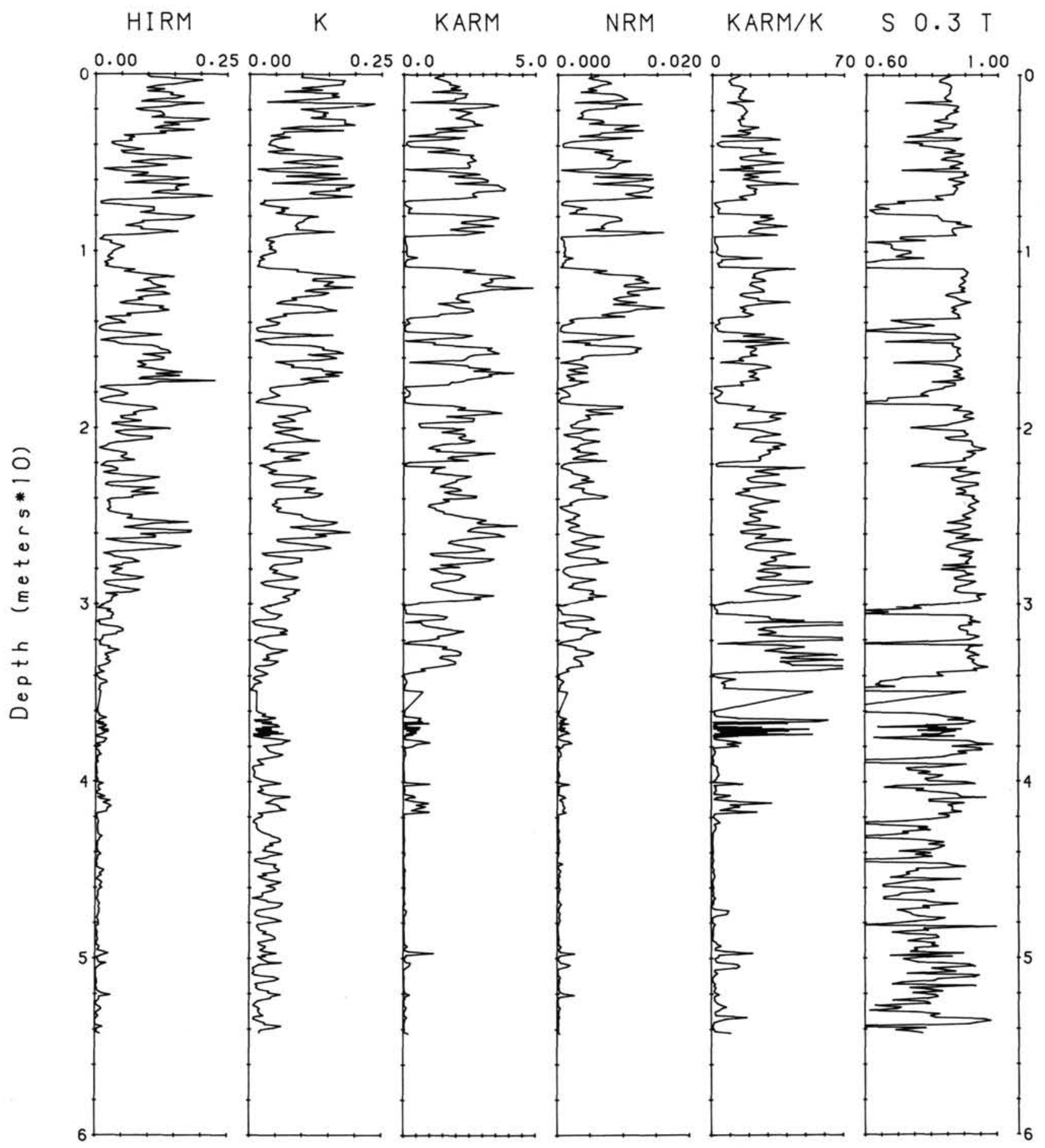

Figure 7. Rock-magnetic stratigraphy of Site 665 . Units: $\mathrm{K} ; \mathrm{K}_{\mathrm{ARM}} \times 10^{-6} \mathrm{SI}$ units; HIRM $\times 10^{-3} \mathrm{~A} / \mathrm{Ma}$. 


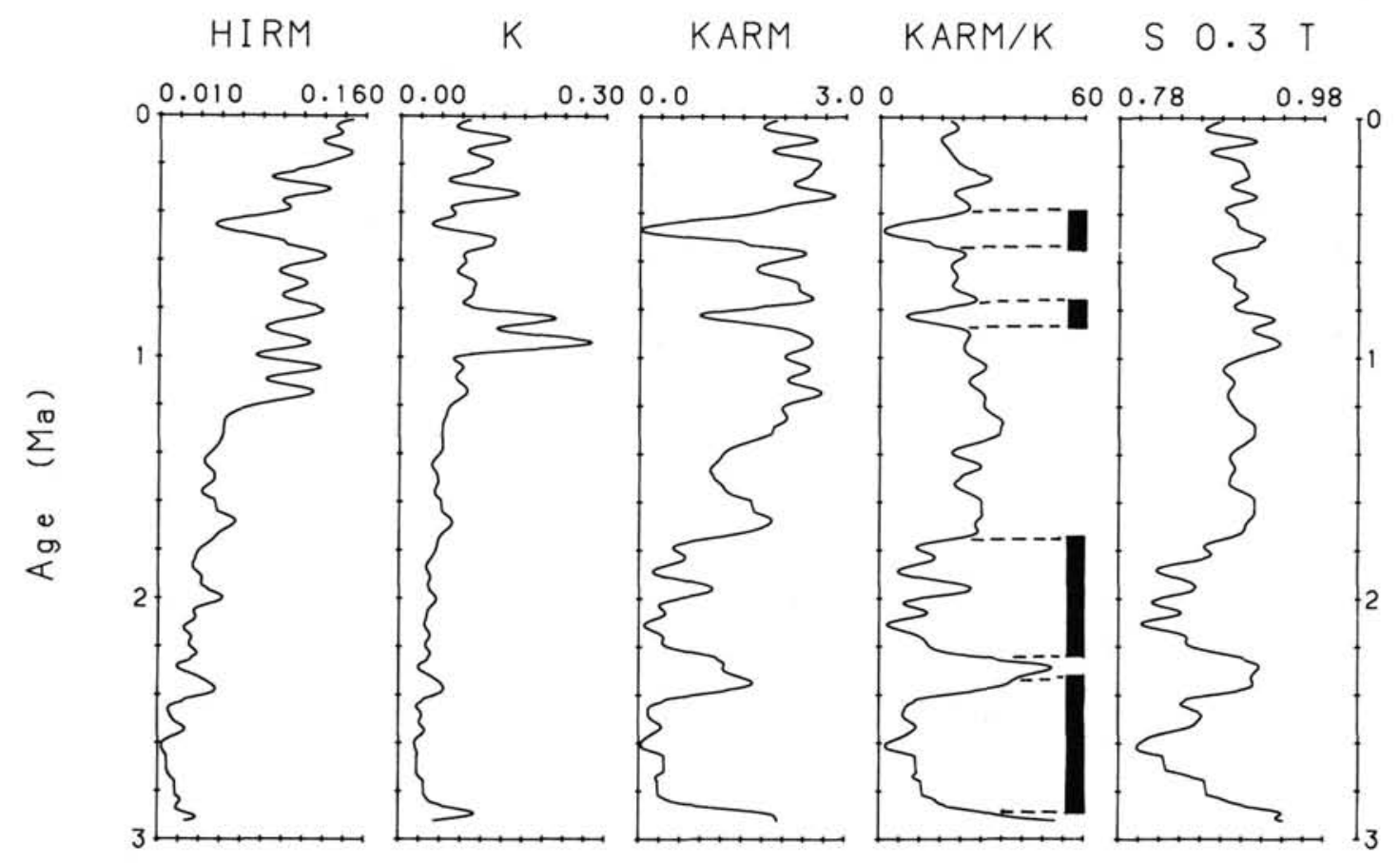

Figure 8. Magnetic accumulation rates for Site 665 . Units: $\mathrm{K} ; \mathrm{K}_{\mathrm{ARM}} \times 10^{-6} \mathrm{~m} / \mathrm{Ma} ; \mathrm{HIRM} \times 10^{-3} \mathrm{~A} / \mathrm{m} . \mathrm{y}$.

\section{Sites 658 and 661}

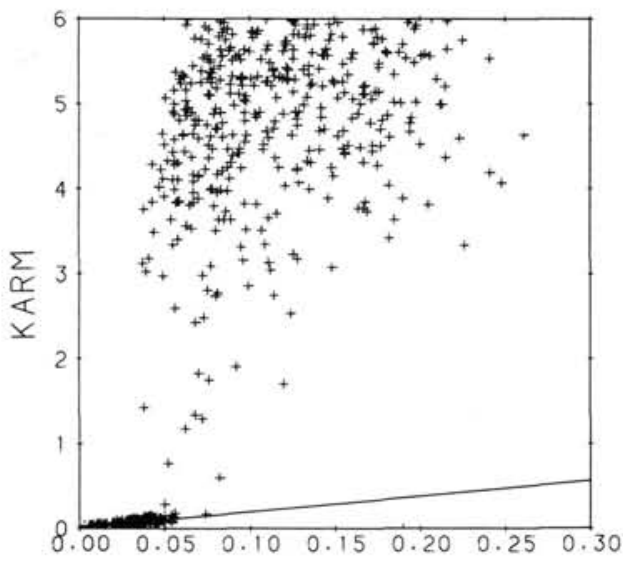

K
Site 659

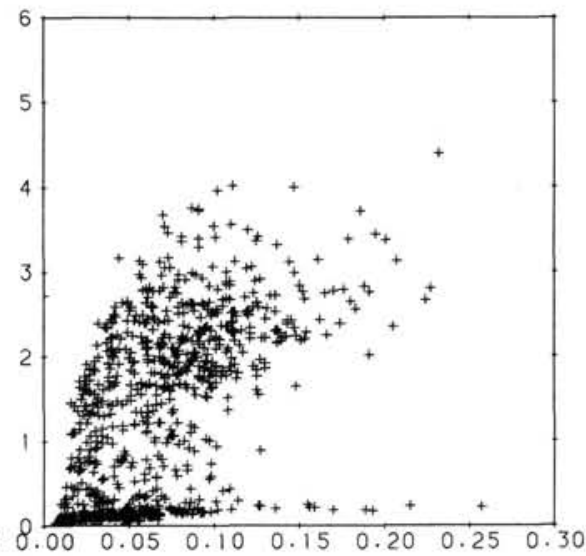

K
Site 665

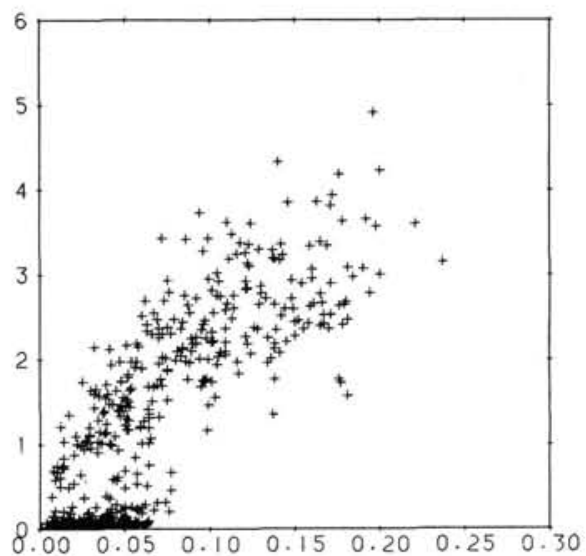

K

Figure 9. $\mathrm{K}$ plotted against $\mathrm{K}_{\mathrm{ARM}}$ for Sites $658,659,661$, and 665 . Units: $\mathrm{K}$ and $\mathrm{K}_{\mathrm{ARM}} \times 10^{-6} \mathrm{SI}$ units. 
ROCK-MAGNETIC STRATIGRAPHY OF SITES 658, 659, 661, AND 665

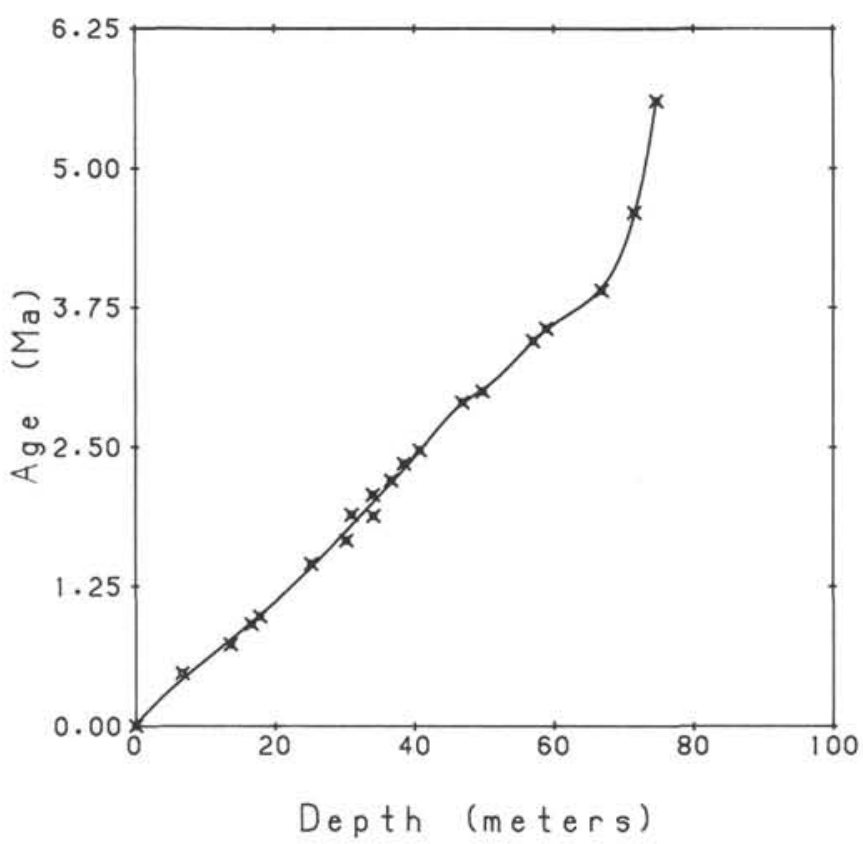

Figure 10. Age model for Site 661.
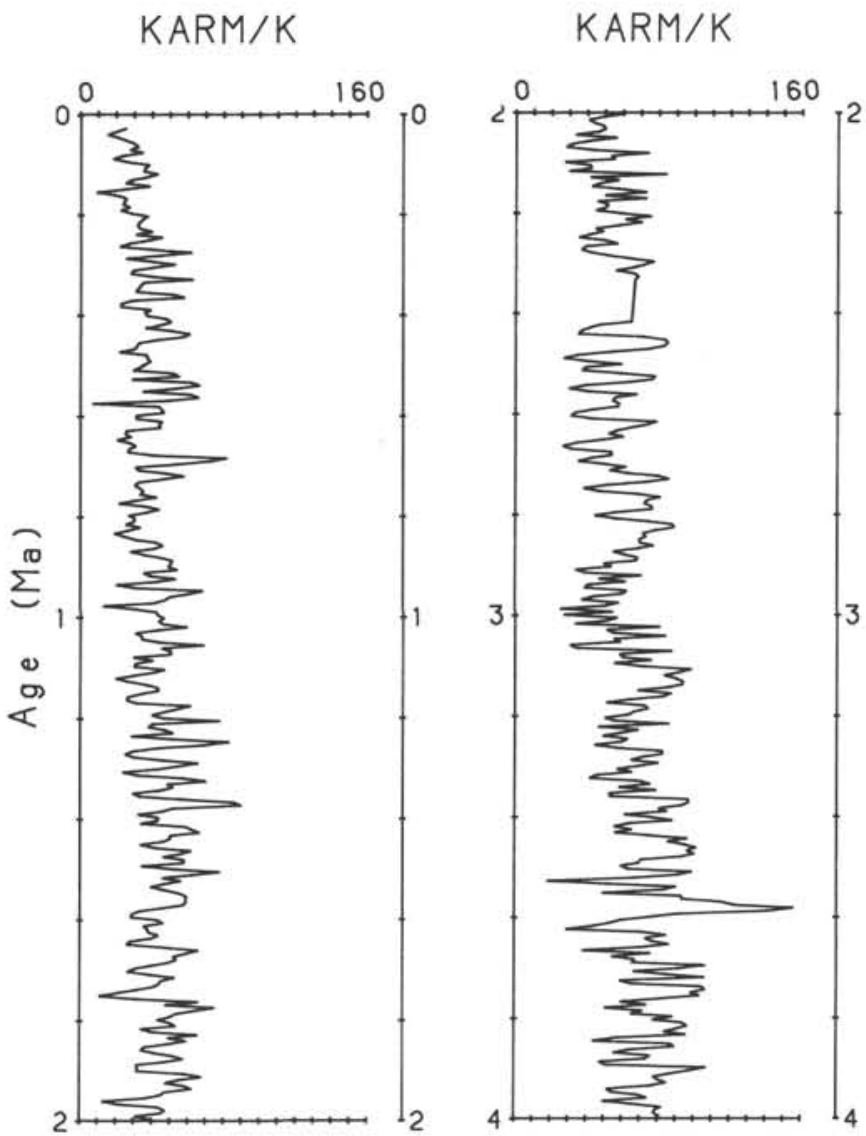

Figure 11. $\mathrm{K}_{\mathrm{ARM}} / \mathrm{K}$ time series for Site 661 . 

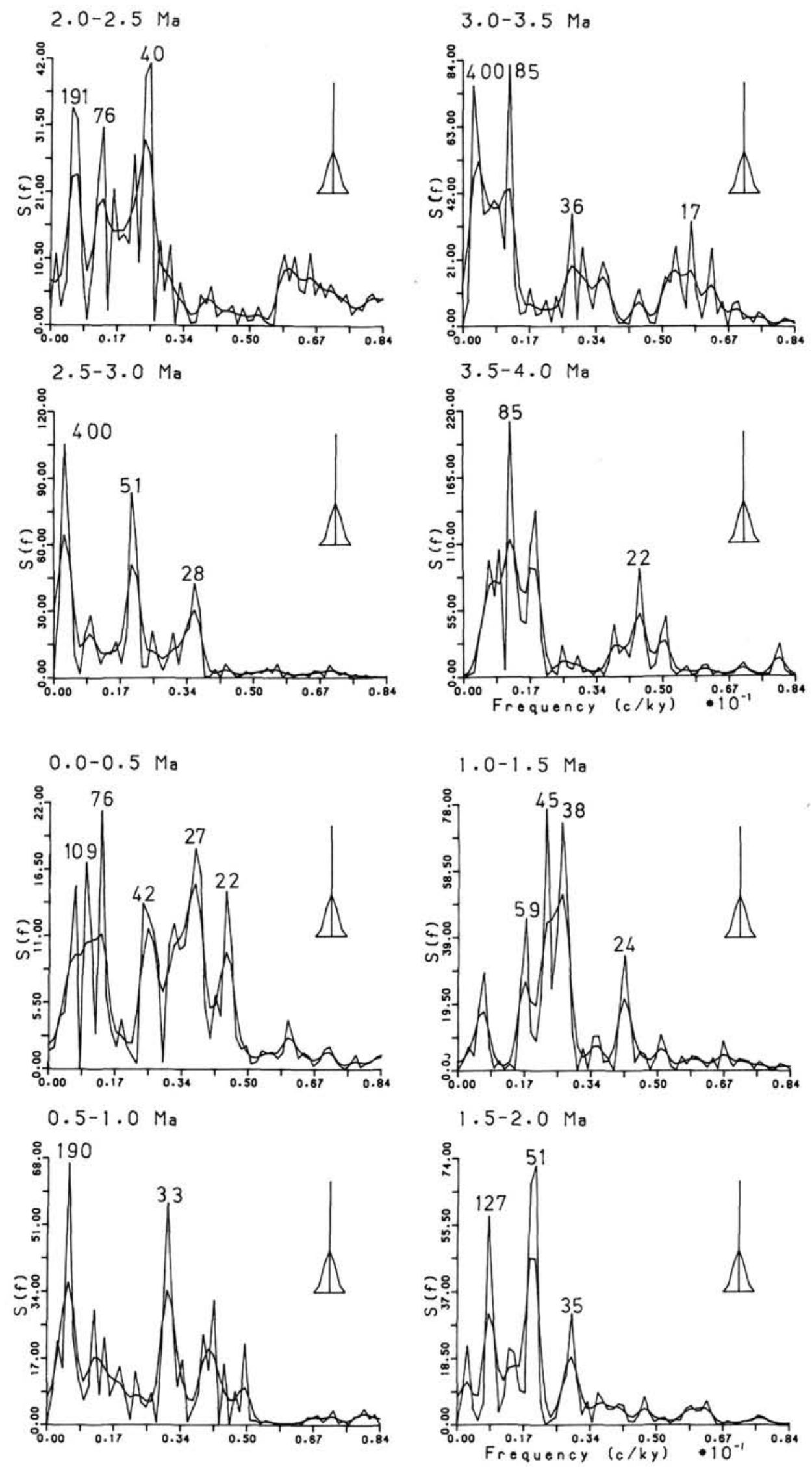

Figure 12. Results of spectral analysis of the $\mathrm{K}_{\mathrm{ARM}} / \mathrm{K}$ time series for Site 661 . 